\title{
ASSESSMENT OF PRODUCTION CONSTRAINTS AND PROFITABILITY OF FLORICULTURE ENTERPRISE IN KANO STATE, NIGERIA
}

\author{
Abbas, M.N ${ }^{1}$, Ibrahim, A $^{2}$. Shehu, Y.A. ${ }^{3}$, Jibrin, M.A. ${ }^{4}$, Hamza, H.I. ${ }^{5}$ and Ali, S. ${ }^{6}$ \\ Department of Agricultural Economics and Management Technology ${ }^{1}$, \\ Department of Bio-Environmental Management Technology $y^{2,3,4}$, \\ Department of Home and Rural Economics ${ }^{5}$, \\ AuduBako College of Agriculture Dambatta, Kano State, Nigeria ${ }^{1,2,3,4,5}$ \\ Department of Agricultural Technology, Bilyaminu Usman Polytechnic Hadejia, Jigawa State, Nigeria ${ }^{6}$
}

https://doi.org/10.35410/IJAEB.2020.5459

\begin{abstract}
Ornamental plant enterprises are an important subsector and treasures for self-employment and livelihood. In spite of its enormous benefit, the subsector enjoyed a level of neglect. This study was conducted and evaluate the production constraints and profitability on floricultural investment in Kano state Metropolitan Local Government Areas (LGAs). A multistage random and purposive sampling techniques were employed in selection of thirty (30) respondents on the basis of mass production and marketing opportunities. Data generated were analysed by means of Descriptive Statistics (percentages Frequencies tables), Gross Margin and Farm Budget methods. Results revealed a mean age of the floriculturists was 25 and ranges between 20 and 65 years. The flora stalls were manned by males as majority (88.33\%) and females consisted of $11.66 \%$ on the basis of ownership and majority with between 1 and 10 year experience while $3.33 \%$ of them had more than 30 years experiences and had education background. The enterprises has a good Margin by self-sales or contracts sales at $\$ 150,000 /$ month average. Problems identified included the cost of management, resources inputs, business space, and pest and diseases invasion. The study recommended increase in institutional support by the Government and Private partners on credit administration, financial and technical support to stall owners and young individuals as paramount for Economic Development and Growth
\end{abstract}

Keywords: Production Constraints, Profitability, Floriculture and Kano State.

\section{INTRODUCTION}

Marketing of ornamental plants involves the intensive Production of flowers and ornamental shrubs. The enterprise involves the science, an art and practice of growing, harvesting, storing, designing and encompasses potted plants (foliage plants and potted flowering plants), bedding and spice plants, cut flowers, cuttings, tree seedlings and other propagating material. Including marketing aspect. It form an important subsector which plays a very role in the income generation to the farmers. The industry has a global recognition as it has vast potential roles in employment generation for both rural and urban dwellers directly or indirectly Usman et al., (2002). The direct job includes those for skilled labour, like researchers, teachers, green house managers, and nursery managers and so forth; while the indirect job includes those of factories that produces chemicals and machineries for the production and processing of floriculture produce Aquaoh (2004). In view of the increasing number of personal houses and corporate 
organization building in Nigeria, the floriculture enterprises has become quite relevant in today business environment as reported by Fagbayide and Jolasum (2002). Ornamental Flora has a great role in carbon sequestration as reported by Berry,(2010).It is prominent and eminent that floriculture industry in Nigeria has received a very little attention in the nation plan for agricultural development Oseni, (2004) and still receiving less concern. This may be attributed to inadequate awareness of the profitability potentials as well as returns.

The current study, therefore; aimed at assessing the production economics and constraints of ornamental horticulture in the study area.

\section{OBJECTIVES OF THE STUDY}

The broad objective of the study was to examine the economic analysis of investment in floricultural plants in Kano metropolitan Kano state, Nigeria. While more specifically, this study aimed to:

i. Describe socio-economic characteristics of the floriculturists in the study area.

ii. Determine the profitability of floriculture enterprise in the study area.

iii. Evaluate some problems affecting floriculture enterprise in the study area.

\section{METHODOLOGY}

\subsection{Study Area}

The study area covered three (3) of Local Government Areas (LGAs) of Kano city, Kano State, Nigeria. The areas lie between latitude $13^{\circ} \mathrm{N}$ and $11^{\circ} \mathrm{L}$ and longitude $8^{0} \mathrm{E}, 10 \mathrm{E}$ and are within the Semi-Arid Sudan savannah zone of West Africa, about 840 Kilometers from the edge of the Sahara desert. It has an attitude of about 472. 45m above sea level (Berry, 1997). Kano state has a population of 9,383,682 persons (NPC 2006). The temperature of Kano state ranges from a maximum of $33^{\circ} \mathrm{C}$ to a minimum of $15.85^{\circ} \mathrm{C}$, though, sometimes during the Hamattan falls to as low as $10^{\circ} \mathrm{C}$. The average rainfall lies between $63.3 \mathrm{~mm} \pm 48.2 \mathrm{~mm}$ in May and $133.4 \pm 59$ in August. The soils in most of Kano State is light or moderate leached yellowish brown and sandy dust like most other savannah parts of Nigeria. The soil fertility supports agricultural activities contributing to the high population density especially in the Kano (Berry 1997).

\subsection{Sampling Technique and Size}

A multistage stage systematic sampling procedure was employed in selecting Municipal Tarauni, Fagge, Local Government Areas (LGAs) of Kano State in the first stage, in the second stage; purposive sampling procedure was employed in selection of flora stalls and randomly sampled respondents operating floriculture enterprises. A total of thirty(30) floriculturists (ten in each) were captured, proportionately; at first sight random view for the interviews.

\subsection{Analytical Tools}

Descriptive statistics such as frequency counts, percentages inferential statistics and chi square analysis were employed. The descriptive statistics used were mean, frequency distribution and percentages. 
Models Specified, as used in the Study

\subsubsection{Descriptive Statistics}

$P=\sum f / N X 100$ 1

Where:

$\mathrm{P}=$ percentage

$f=$ Frequency

Mean

$=\sum \mathrm{X}_{\mathrm{i}} / \mathrm{n}$

Mean $=\sum \mathrm{X}_{\mathrm{i}} \mathrm{f}_{\mathrm{i}} / \sum \mathrm{f}_{\mathrm{i}}$

Where: $\sum=$ means total population of respondents, $\mathrm{N}=$ population mean. $\mathrm{X}=$ number of responses, $\mathrm{n}=$ number of observations $1,2,3 \ldots \mathrm{i}-\mathrm{j}, \%=$ percentage (out of hundred). It was employed to achieve objective I and III.

\subsubsection{Farm Budget Analysis}

A farm budget analysis was used to achieve the determination of production costs and returns to floricultural plants production in the study area. The returns to farmers labour management was expressed in Naira per Hacter ( $\mathrm{N} / \mathrm{ha})$. Costs comprised the Fixed Cost $\left(\mathrm{FC}_{\mathrm{x}-\mathrm{j}}\right)$ includes cost of land rent, labour and depreciation charges on simple farm tool and production while Variable Cost (VC)TVCs includes cost of fertilizer, seed agro-chemical, hiring cost or repair, maintenance and transportation and Returns were revenues accrued from the produce sold (Total Value Product) $\mathrm{TVP}_{\mathrm{y}}$ less the expenses TFC and TVC.

\section{Where:}

3.3.3 Gross Margin Analysis (GM)

GM=TR-TFC -

TVC. 4

$\mathrm{TR}=$ Total Revenues $(\mathrm{N})$

TVC $=$ Total Variable Cost ( $($ )

TFC=Total Fixed Cost $(\mathrm{N})$

$\mathrm{GM}=$ Gross Margin ( $\mathrm{N} / \mathrm{plot})$

$\mathrm{NFI}=$ Net Farm Income/ ( $)$.

The model was employed to achieve objective I and III.

\section{RESULTS AND DISCUSSIONS}

\subsection{Socioeconomic Characteristics of Respondents}

Socioeconomic characteristics were identified to have a base on the farmers' social and economic background and to understand how these help them in conducting their activities. The 
variables considered were: Age, Gender, Marital status, Education Backgrounds, Size of holding and Years of Experience in the floral business.

\subsubsection{Distribution of Respondents According to Age}

The results revealed that proportions of $40.00 \%$ were within the age bracket of $20-30$ years. The result further shows $23.33 \%$ of them were within 31-50 years. The implication of this finding was that those floriculturists were young and middle aged. Young persons were strong, agile and willing to take risk. The report corroborates with finding of the Musa et al., (1998), Danwanka (2004) which says that young people can take risk in anticipation of high return.

Table I: Age Distribution of Respondents in Kano Metropolitan Area

\begin{tabular}{lcc}
\hline $\begin{array}{l}\text { Age }(\text { years }) \\
(\%)\end{array}$ & Frequency & Percentage \\
\hline $20-30$ & 12 & 40.00 \\
$31-40$ & 7 & 23.33 \\
$41-50$ & 6 & 20.00 \\
50 above & 5 & 15.00 \\
$\quad$ Total & $\mathbf{3 0}$ & $(\mathbf{1 0 0})$ \\
\hline
\end{tabular}

Source: Field survey, (2017)

\subsubsection{Distribution of Floriculturists according to Gender}

Result in table 2 shows that male respondents constitutes $90.00 \%$ while proportions of $10.00 \%$ were females. The possible explanation for this finding might not be unconnected to the sociocultural set-up of the people in the area where men were the breadwinners of the households while female were home makers.

Table 2: Gender Distribution of Floriculturists in Kano Metropolitan

\begin{tabular}{lcc}
\hline Gender & Frequency & Percentage (\%) \\
\hline Male & 27 & 90.00 \\
Female & 3 & 10.00 \\
Total & $\mathbf{3 0}$ & $\mathbf{( 1 0 0 )}$ \\
\hline
\end{tabular}

Source: Field survey, (2017)

\subsubsection{Distribution of Respondents According to Education Background}

Educational level of respondents has a great influence on floriculturists' management ability. Individual's level of education is assumed to affect the nature and pattern of his or her business. Thus, it determines to overall success of the floriculture enterprise farm manager. Table 3 shows that majority of the floriculturists within Kano city flora stalls had attained tertiary educational 
level (36.66 percent), 26.66 percent had secondary school education, 33.33\% of them had primary school education and $3.33 \%$ had adults and non-formal school. These show that floriculture entrepreneurs in the study area were educated and relates to the Adams (1992) findings who revealed that; education is an essential element in all endeavours.

Table 3: Distribution of Respondents According to Education Background

\begin{tabular}{lll}
\hline Education Level & Frequency & Percentage \\
\hline Tertiary & 11 & 36.66 \\
Secondary & 8 & 26.66 \\
Primary & 10 & 33.33 \\
Adult and - formal & 01 & 3.33 \\
$\quad$ Total & $\mathbf{3 0}$ & $\mathbf{( 1 0 0 )}$ \\
\hline
\end{tabular}

Source: Field survey, (2017)

\subsection{Production Cost and Revenue of Floriculture Enterprise Based on Farm Gate price}

Table shows the average revenue of $\$ 150,000$ while the total variable cost of $\$ 20,000$ was realised. The Gross Margin of $\$ 55,000$, the Net Farm Income $(\$ 105,000)$ and the benefit-cost ratio was 1.5 .The finding reveals that floral enterprising is profitable. Family labour gives the return to farmer labour management Muhammad et al., (2012).

Table 4: Production Cost and Revenue of Floriculture Enterprise Based on Farm gate Price

\begin{tabular}{lcl}
\hline Variable Cost & Average (N/plot) & TVC \\
\hline Land preparation & $5300: 00$ & 26.5 \\
Seed and nursery & $4450: 00$ & 22.25 \\
Planting & $1,100: 00$ & 05.5 \\
Watering & $2,400: 00$ & 12.0 \\
Water charge & $500: 00$ & 02.5 \\
Fertilizers & $3,300: 00$ & 16.5 \\
Organic manure & $2,000: 00$ & 10.0 \\
Insecticides & $350: 00$ & 01.75 \\
Transportation & $800: 00$ & 04.0 \\
Total Variable Cost & $\mathbf{2 0 , 0 0 0 : 0 0}$ & $\mathbf{( 1 0 0 )}$ \\
Fixed Cost & & \\
Rent on Land & $30,000: 00$ & \\
Total Fixed Cost & $\mathbf{4 5 , 0 0 0 : 0 0}$ & \\
Total Cost & $\mathbf{9 5 , 0 0 0 : 0 0}$ & \\
Total Revenue & $\mathbf{1 5 0 , 0 0 0 : 0 0}$ & \\
GM (TR-TV) & $\mathbf{5 5 , 0 0 0 : 0 0}$ & \\
NFI (GM-TFC) & $\mathbf{1 0 5 , 0 0 0 : 0 0}$ & \\
Benefit-Cost Ratio & $\mathbf{1 . 5}$ & \\
Source: Computed from Field Survey, (2017). &
\end{tabular}




\subsection{Problems to Development of Floriculture Enterprise}

Result in table 5 shows that problems included inadequate capital to expand the scale of production, capital $(40.00 \%)$, water shortage problems (13.33\%), pests and diseases $(20.00 \%)$, low demand of the floral (6.66\%), problems of land 6.66 and $16.66 \%$ other problems.

Table 5: Distribution of Respondents According to Constraints to Floriculture Enterprises

\begin{tabular}{lcc}
\hline Problems & Frequency & Percentage (\%) \\
\hline Inadequate capital & 12 & 40.00 \\
Lack/shortage of water & 4 & 13.33 \\
Pest and disease & 6 & 20.00 \\
Law demand of the floral & 2 & 6.66 \\
Problem of land & 2 & 6.66 \\
Other Constraints & 5 & 16.66 \\
\multicolumn{1}{c}{ Total } & $\mathbf{3 0}$ & $\mathbf{( 1 0 0 )}$
\end{tabular}

Source: Field survey, (2017)

\section{CONCLUSION AND RECOMMENDATIONS}

\subsection{Conclusion}

The study examined the economics of Ornamental floriculture in Kano metropolitan area. The enterprise was profitable and sourced their capitals by means of personal savings (93.33\%). The average capital investment of the respondents were within $\$ 1,000-\$ 100,000$.Income spent on variables of $\$ 10,000-\$ 100,000$,Total Variable Cost and $\$ 150,000$ Revenue realized. Constraints identified with the floral Enterprises were; lack of capital (40.00\%) and pest and disease among other Constraints.

\subsection{Recommendation}

Based on the findings of this study, it has been recommended that:

- Facility assistance in form of credit package, or start up loan should be made available to farmers by the Government and or Financial Institution to enable the floriculturists to increase their scale of production for enhancement of livelihood and economic development.

- Young school leavers and other young individuals, should be encouraged on the potentials of the enterprise, consequently contribute to reduction in youth unemployment currently being experienced in the country. 
International Journal of Agriculture, Environment and Bioresearch

Vol. 5, No. 01; 2020

ISSN: $2456-8643$

- Researches within the nursery sub-sector should be encouraged and be funded to assess water management technologies, recycling protocols and distribution systems.

\section{REFERENCES}

[1] Acquaah, G. (2002). Horticulture Principles and Practices. Pearson Education Inc. Singapore.

[2] Awasthi, D., Jaggi, R. and Padmanand, V. (2006). Manual for Entrepreneurs by Entrepreneurship Development Institute of India, Ahmedabad.

[3] Baiyewu, R.A. Amusa, N.A. and Olayiwola, O. 2005. Survey on the use of ornamental plants for environmental management in southwestern Nigeria. Research Journal of Agriculture and Sciences 1(3):237-240.

[4] Berry, I. (1997). Kano state government Agro forestry in the west Sahel Resources Management for Arid and Semi-Arids www.kanostate.net/enironment.

[5] Chukwuma, O.(2010), Ornamental Plants Beautiful and Enrichment in Tribune NewspaperNigeria,Retrieveon20 ${ }^{\text {th }}$ August,2010.Fromwww.tribute.com/st/index.Php/busin essense/1443- ornamental plants beautify enriching./ML.

[6] Fagbayide, J.A. and Jolason, O.D. (2002). Assessment of Floriculture Industries and Level of its Appreciation in Lagos Metropolis. A Paper presented at a proceeding of Annual Conference of Horticultural Society of Nigeria.

[7] Fakayode, B.S., Adewumi, M.O., Rahji, M.A.Y. and Jolaiya, J.A. (2008). Viability and Resource use in Ornamental Plants Nursey Business in Nigeria. European Journal of Social Science Vol. 6 (4):19-28.

[8] George, A. (2002).Horticulture Principles and Practices. Book published by Pearson Education Asia.

[9] Muhammad, L. A. Adenuga, A.H, Olatinwo, K.B. and Sa'adatu, T.A. (2012). "Economic Analysis of Floricultural plant production in Kwara State North central Nigeria", Department of Agricultural Economics and Farm Management, University of Ilorin Nigeria.

[10] Oseni, T.O. (2004). Integrated Horticultural Crop Production and Extension Services. A paper presented at the 22nd Annual Conference of Horticultural Society of Nigeria (HORTSON).

[11] Oseni, T.O. Auwal, B.M. and Bustwat, I.S. (1998). Agricultural Development in the $21^{\text {st }}$ Century, Concept and Strategies Pp.235-238 Proceeding of 14 th annual conference of Farm Management Association Nigeria (FAMAN) held at Abubakar Tafawa Balewa University Bauchi, Bachi State, Nigeria on $20^{\text {th }}-23^{\text {rd }}$ September 1998. 
International Journal of Agriculture, Environment and Bioresearch

Vol. 5, No. 01; 2020

ISSN: $2456-8643$

[12] Randhawa, G.S., Mukhopadhyay,A. (2001).Floriculture in India: Book published by Allied Publishers Limited, New Delhi.

[13] Society of American Florist (2006). Overview of floriculture industry. Society of American Florist Bulletin 2006 View publication.

[14] Usman, M. and Ashfaq, M.(2013). Economic Analysis of Gladiolus Production in Punjab, Pakistan. J. Agric. Res. 51(3): 317-326. 